\title{
Toward the Resegregation of Southern Schools: African American Suburbanization and Historical Erasure in Freeman v. Pitts
}

\section{Daniel Amsterdam}

This article reconstructs the story behind Freeman v. Pitts (1992), one of the main US Supreme Court cases that made it easier for school districts to terminate court desegregation orders and that, in turn, helped to propel a widely documented trend: the resegregation of southern schools. The case in part binged on the question of whether school officials in an Atlanta suburb were responsible for the racial segregation that had developed in the area alongside the rapid settlement of African Americans there in the late twentieth century. Thus, along with shedding new light on how the South transitioned from an era focused on desegregation to one enabling resegregation, the article makes contributions to two areas of increasing scholarly interest: the history of African American suburbanization and the history of suburban school districts. Finally, the article underscores disconcerting patterns in how the Supreme Court utilized history in Freeman.

In the final years of the twentieth century, federal judges began terminating scores of school desegregation orders across the United States. This trend especially reshaped school districts in the South, which, for a variety of reasons, had generally desegregated more extensively than school systems in the North and West. ${ }^{1}$ With the end of court

Daniel Amsterdam (daniel.amsterdam@hsoc.gatech.edu) is an Assistant Professor in the School of History and Sociology at the Georgia Institute of Technology and the author of Roaring Metropolis: Businessmen's Campaign for a Civic Welfare State (University of Pennsylvania Press, 2016). He would like to thank Nancy Beadie, Marcia Borowski, Ansley Erickson, Adam Goodman, Julia Gunn, John Krige, Todd Michney, Kathryn Nicholas, Johnny Smith, Steve Usselman, Joy Williamson-Lott, and the anonymous reviewers.

${ }^{1}$ Among other reasons, desegregation in the South went further than elsewhere in the country because school districts often encompassed larger swaths of metropolitan areas in the South (including cities, suburbs, etc.) and thus a comparatively large number of African American and white students. Most famously in Milliken v. Bradley, 418 U.S. 717 (1974), the US Supreme Court rejected efforts to desegregate across school district boundaries, a stricture that particularly limited desegregation's reach in northeastern and midwestern metropolitan areas, where jurisdiction over schooling was often divided between many different school districts. On this issue, see Gary Orfield, "Turning Back to Segregation," in Dismantling Desegregation: The 
oversight, many southern school districts returned to segregative practices quickly and with impunity, helping to propel a widely documented phenomenon: the resegregation of southern schools. ${ }^{2}$ The era of school desegregation was coming to a close. It has been now for nearly a generation. Nonetheless, historians have only begun to tell the story behind this highly consequential shift in American educational history. To be sure, scholars have detailed how popular opposition to court-ordered desegregation in the 1950s, 1960s, and 1970s contributed to a rising tide of political conservatism that in part sought to stymie school desegregation. ${ }^{3}$ Historians have also written case studies that touch on the end of desegregation efforts in particular communities, while others, such as James T. Patterson, have offered broad overviews that discuss facets of desegregation's final days. ${ }^{4}$

Quiet Reversal of Brown v. Board of Education, ed. Gary Orfield and Susan E. Eaton (New York: New Press, 1996), 10-12, 14-15.

${ }^{2} \mathrm{On}$ the resegregation of southern schools in recent decades, see Sean F. Reardon, et al., "Brown Fades: The End of Court-Ordered School Desegregation and the Resegregation of American Public Schools," Journal of Policy Analysis and Management 31, no. 4 (Fall 2012), 876-904; Byron Lutz, "The End of CourtOrdered Desegregation," American Economic Journal: Economic Policy 3, no. 2 (May 2011), 130-68; John Charles Boger and Gary Orfield, eds., School Resegregation: Must the South Turn Back? (Chapel Hill: University of North Carolina Press, 2005); and Gary Orfield, et al., Brown at Sixty: Great Progress, a Long Retreat and an Uncertain Future, May 15, 2014, The Civil Rights Project, https://www.civilrightsproject.ucla. $\mathrm{edu} / \mathrm{research} / \mathrm{k}-12$-education/integration-and-diversity/brown-at-60-great-progress-a-long-retreat-and-an-uncertain-future.

${ }^{3}$ Leading examples of such scholarship include Matthew D. Lassiter, Silent Majority: Suburban Politics in the Sunbelt South (Princeton, NJ: Princeton University Press, 2006); Kevin M. Kruse, White Flight: Atlanta and the Making of Modern Conservatism (Princeton, NJ: Princeton University Press, 2005); Ronald P. Formisano, Boston against Busing: Race, Class, and Ethnicity in the 1960s and 1970s, 2nd ed. (Chapel Hill: University of North Carolina Press, 2004); Jonathan Rieder, Canarsie: The Jews and Italians of Brooklyn against Liberalism (Cambridge, MA: Harvard University Press, 1985); and Matthew F. Delmont, Why Busing Failed: Race, Media, and the National Resistance to School Desegregation (Berkeley: University of California Press, 2016).

${ }^{4}$ Examples of historical scholarship that discuss, to varying degrees of depth, the end of desegregation efforts in particular communities include Ansley T. Erickson, Making the Unequal Metropolis: School Desegregation and Its Limits (Chicago: University of Chicago Press, 2016); Tracy E. K'Meyer, From Brown to Meredith: The Long Struggle for School Desegregation in Louisville, Kentucky, 1954-2007 (Chapel Hill: University of North Carolina Press, 2013); Brett V. Gadsden, Between North and South: Delaware, Desegregation, and the Myth of American Sectionalism (Philadelphia: University of Pennsylvania Press, 2013); Howell S. Baum, Brown in Baltimore: School Desegregation and the Limits of Liberalism (Ithaca, NY: Cornell University Press, 2010); Joshua M. Dunn, Complex Justice: The Case of Missouri v. Jenkins (Chapel Hill: University of North Carolina Press, 2008); Stephen S. Smith, Boom for Whom?: Education, Desegregation, and Development in Charlotte (Albany: State University of New York 
Still, many of the factors that propelled desegregation's denouement in the 1980s, 1990s, and after remain understudied, including landmark US Supreme Court decisions that strongly encouraged desegregation's demise. ${ }^{5}$

This article reconstructs the story behind one of those pivotal US Supreme Court cases: Freeman v. Pitts (1992), a decision that made it significantly easier for school districts across the country to end court desegregation decrees. ${ }^{6}$ In Freeman, the Supreme Court considered the battle over desegregation in the school district of DeKalb County, Georgia, a sprawling, populous suburban area adjacent to Atlanta. The court's ruling in the case was unanimous, but multiple justices filed or signed separate opinions that revealed sharp disagreement about the particulars of the case. Those particulars hinged on the question of whether the DeKalb County School District was at least partially responsible for the stark pattern of racial segregation that had developed in the suburb amid the fast-paced settlement of African Americans there- a trend that began in the late 1960s, accelerated dramatically in the 1970s, and continued in the years thereafter. Thus, along with adding important detail to the story of how the South transitioned from an era focused on school desegregation to one enabling resegregation, examining Freeman sheds light on two areas that have garnered increasing scholarly attention in recent years: first, the disparate histories of America's diverse array of suburban school districts, a topic that historians of public education have recently started to examine, moving beyond their traditional focus

Press, 2004); Formisano, Boston against Busing; Gregory S. Jacobs, Getting Around Brown: Desegregation, Development, and the Columbus Public Schools (Columbus: Ohio State University Press, 1998); Robert A. Pratt, The Color of Their Skin: Education and Race in Richmond, Virginia (Charlottesville: University of Virginia Press, 1992); Glenn M. Linden, Desegregating Schools in Dallas: Four Decades in the Federal Courts (Dallas: Three Forks Press, 1995); and Sarah Garland, Divided We Fail: The Story of an African American Community that Ended the Era of School Desegregation (Boston: Beacon Press, 2013). James T. Patterson briefly discusses the late days of school desegregation. James T. Patterson, Brown v. Board of Education: A Civil Rights Milestone and Its Troubled Legacy (New York: Oxford University Press, 2001), 191205, 209-14.

${ }^{5}$ For historical works that intensively examine other major recent US Supreme Court cases that, like Freeman v. Pitts, helped encourage school desegregation's end, see especially K'Meyer, From Brown to Meredith; Dunn, Complex Justice; and Garland, Divided We Fail.

${ }^{6}$ On Freeman's significance for school desegregation, see, Dunn, Complex Justice, 159, 161-63; Patterson, Brown v. Board of Education, 198-99; Erwin Chemerinsky, "The Segregation and Resegregation of American Public Education: The Court's Role," in School Resegregation, ed. Boger and Orfield, 38-41. 
on rural and especially urban schools and, second, the history of African American suburbanization. ${ }^{7}$

Indeed, the story behind Freeman underscores the wide variety of discriminatory practices that encouraged the growth of segregated African American areas in an increasing number of suburbs in the late twentieth century, a period that historians of African American suburbanization and of US suburbia more generally have just started to examine. As Andrew Wiese explains in one of the few discussions of the topic by an historian, millions of African Americans moved to the suburbs in the late twentieth century, but "rather than upsetting the familiar stratification of metropolitan areas into white and black spaces, the suburban explosion expanded it over a greater area," so much so that by 1990 "the majority of black suburbanites lived in racially segregated neighborhoods." ${ }^{8}$ At the same time, examining Freeman's history draws attention to the role that school officials and even the details of court orders in school desegregation cases themselves could play in propelling this trend. With important exceptions, historians of African American suburbanization have paid scant attention to schooling. ${ }^{9}$ As a flurry of recent historical scholarship on race, schools,

${ }^{7}$ Examples of the small but growing literature on suburban schools include Erickson, Making the Unequal Metropolis; John L. Rury, "Trouble in Suburbia: Localism, Schools, and Conflict in Postwar Suburbia," History of Education Quarterly 55, no. 2 (May 2015), 133-63; Emily E. Straus, Death of a Suburban Dream: Race and Schools in Compton, California (Philadelphia: University of Pennsylvania Press, 2014); Matthew D. Lassiter, "Schools and Housing in Metropolitan History: An Introduction," Journal of Urban History 38, no. 2 (March 2012), 195-204; Jack Dougherty, "Shopping for Schools: How Public Education and Private Housing Shaped Suburban Connecticut," Journal of Urban History 38, no. 2 (March 2012), 205-24; and Jack Dougherty, "Bridging the Gap between Urban, Suburban, and Educational History," in Rethinking the History of American Education, ed. William J. Reese and John L. Rury (New York: Palgrave Macmillan, 2008), 245-59. On the history of African American suburbanization, see especially Andrew Wiese, Places of Their Own: African American Suburbanization in the Twentieth Century (Chicago: University of Chicago Press, 2004); N. D. B. Connolly, A World More Concrete: Real Estate and the Remaking of Jim Crow South Florida (Chicago: University of Chicago Press, 2014); Bruce D. Haynes, Red Lines, Black Spaces: The Politics of Race and Space in a Black Middle-Class Suburb (New Haven, CT: Yale University Press, 2001); and Straus, Death of a Suburban Dream.

${ }^{8}$ Wiese, Places of Their Own, 258.

${ }^{9}$ In his seminal study of African American suburbanization, for instance, Andrew Wiese draws attention to a number of the dynamics in the housing market that this article highlights when discussing racial transition in suburban areas during the period, but he does not explore the role educational dynamics may have played in helping to drive racial change. Weise, Places of Their Own, 209-92. Bruce Haynes discusses schools only briefly in his study of a black middle-class suburb outside New York City. Haynes, Red Lines, Black Spaces, esp. 85-6, 101-05. Emily Straus's study of Compton, California, is one of the few works that closely examines 
and metropolitan development has highlighted in other contexts, however, educational dynamics have frequently influenced racial settlement patterns in metropolitan America-including, this article shows, in late twentieth-century DeKalb County. ${ }^{10}$

Finally, reconstructing the story behind Freeman raises troubling questions about how the US Supreme Court utilized history in its landmark ruling in the case. The court's decision in Freeman failed to engage with a critical moment in the case's past, despite the urging of attorneys during oral arguments. In addition, without basing its assertions on testimony or other evidence, the court in Freeman made the highly questionable assertion that history itself - specifically the passage of time - could ameliorate past discrimination by school officials and, thus, could provide a rationale for terminating court desegregation decrees if other criteria were also met. School desegregation was initially a project that sought to remedy egregious historic wrongs. In Freeman, by contrast, the court deployed a selective and otherwise problematic view of history and helped make school desegregation itself a thing of the past.

\section{The Racial Reconfiguration of DeKalb County}

Although a slice of the city of Atlanta juts into a portion of DeKalb County, the overwhelming majority of DeKalb sits immediately east of Atlanta's city limits. With the minor exception of the four-squaremile municipality of Decatur, which runs its own school system, this expansive, suburban area is coterminous with the DeKalb County School District (DCSD) and constitutes the area discussed in this article. The small portion of DeKalb County that overlaps with Atlanta

African American suburbanization alongside the history of public education, albeit for a significantly earlier period than this article. Straus, Death of a Suburban Dream.

${ }^{10}$ For recent historical scholarship interrogating the relationship between schooling, race, and metropolitan development, see especially Erickson, Making the Unequal Metropolis; Andrew R. Highsmith, Demolition Means Progress: Flint, Michigan, and the Fate of the American Metropolis (Chicago: University of Chicago Press, 2015); Ansley T. Erickson and Andrew R. Highsmith, "Segregation as Splitting and Joining: Schools, Housing, and the Many Modes of Jim Crow," American Journal of Education 121, no. 4 (Aug. 2015) 563-95; Lassiter, "Schools and Housing in Metropolitan History"; Dougherty, "Shopping for Schools"; Karen Benjamin, "Suburbanizing Jim Crow: The Impact of School Policy on Residential Segregation in Raleigh," Journal of Urban History 38, no. 2 (March 2012), 225-46; Ansley T. Erickson, "Building Inequality: The Spatial Organization of Schooling in Nashville, Tennessee, after Brown," Journal of Urban History 38, no. 2 (March 2012), 247-70; and Dougherty, "Bridging the Gap between Urban, Suburban, and Educational History." 
proper is not part of the DCSD but rather the city of Atlanta's public school district.

Settlement in suburban DeKalb County remained relatively sparse until World War II, but the area's population grew explosively thereafter, rising from roughly 40,000 in 1940 to 345,000 in 1970 . The overwhelming majority of these newcomers were white, as widespread racial discrimination-especially in the provision of home loans insured by the Federal Housing Administration (FHA)-made it notoriously difficult for African Americans to settle in suburban America in the postwar years. In 1970, African Americans made up only 7 percent of suburban DeKalb's population. Yet as shown in Figures 1 and 2, in the late 1960s increasingly segregated African American areas began to spread rapidly across the southern half of suburban DeKalb, replacing formerly white neighborhoods and dwarfing the small, predominantly African American enclaves that had developed in the county in earlier periods. ${ }^{11}$

Multiple forces drove this trend. Either explicitly or through later interpretations of its provisions, the Fair Housing Act of 1968 outlawed a variety of discriminatory practices that had plagued American housing markets in earlier years, from "blockbusting" and "redlining" to realtors' steering clients to rent or purchase homes in certain neighborhoods based on race. Yet many of these practices continued in suburban DeKalb County to varying degrees during the 1970s, 1980s, and after. State-level policies in Georgia hardly helped matters. The Georgia legislature put the state's real estate commission in charge of guaranteeing fair access to housing in the wake of the 1968 federal act's passage. At least through the mid-1970s, all five members of the commission were white realtors. As one local activist complained, state officials had left foxes "guarding the hen house."12

${ }^{11}$ US Bureau of the Census, Sixteenth Census of the United States: 1940: Population, Volume II, Part 2, Florida-Iowa (Washington, DC: Government Printing Office, 1943), 325, 364; US Bureau of the Census, 1970 Census of Population, Volume 1, Characteristics of the Population, Part 12: Georgia (Washington, DC: Government Printing Office, 1973), $94,122,130$. These population figures apply to the geographic area encompassed by the DeKalb County School District. They exclude the city of Decatur and the part of DeKalb County that overlaps with the city of Atlanta. On discrimination in the provision of FHA-backed home loans, see especially David M. P. Freund, Colored Property: State Policy and White Racial Politics in Suburban America (Chicago: University of Chicago Press, 2007); and Kenneth T. Jackson, Crabgrass Frontier: The Suburbanization of the United States (New York: Oxford University Press, 1985).

${ }^{12}$ John Huey, "Real Estate Panel Hit for Inaction," Atlanta Constitution, Sept. 24, 1974, 5A. On the Fair Housing Act of 1968 and its weaknesses, see, for instance, Douglas S. Massey and Nancy A. Denton, American Apartheid: Segregation and the Making of the Underclass (Cambridge, MA: Harvard University Press, 1993), 195200; and Wiese, Places of Their Own, 223-25. 
Meanwhile, the commission employed only two staff members to investigate housing complaints in the entire state. Victims of housing discrimination could seek redress in federal courts, but doing so often entailed an expensive, time-consuming process. Alternately, one could file a complaint with the US Department of Justice. At least early in the period, however, either route depended largely on everyday apartment and house hunters being aware of what were still new rights. ${ }^{13}$

Amid this environment of minimal enforcement, blockbusting ran rampant in southwestern sections of suburban DeKalb County in the late 1960s and 1970s. In 1969, a fair housing activist claimed that at least thirty real estate agencies in southwestern DeKalb-specifically in the Candler-McAfee section, just east of Atlanta's city limits-were engaging in a variety of classic blockbusting techniques, from capitalizing on white racism to whipping up fears that incipient racial change was going to destabilize property values, thus encouraging white homeowners to sell. ${ }^{14}$ One DeKalb resident described a realtor bragging that "she liked to see white people 'run' from transitional neighborhoods because she 'made a lot of money off of colored people."'15 Other residents of southwestern DeKalb complained that realtors were attempting to induce white panic by "bringing car loads" of African Americans who were likely on realtors' payrolls to view properties that were for sale in predominantly white neighborhoods. ${ }^{16}$ Real estate agents also reportedly urged white homeowners to sell by making false claims that the county had decided to build a new incinerator and hospital in southwestern DeKalb, thus threatening home prices. Blockbusting in southwestern DeKalb began to abate by the late 1970s thanks to a rising number of official complaints and the enactment of new county regulations, including one that sought to curb white anxieties by limiting how long a realtor could display a "Sold" sign. ${ }^{17}$

${ }^{13}$ Huey, "Real Estate Panel Hit for Inaction." On early hindrances to litigation or to filing complaints with state and local officials, see, for instance, Bill Montgomery, "Housing Bias Case Is Landmark Event," Atlanta Constitution, Nov. 17, 1974, 6A.

14"The Housing Pressures," Atlanta Constitution, Feb. 1, 1969, 4.

${ }^{15}$ Margaret, Hurst, "Blockbust Profit Claims Reported," Atlanta Constitution, Aug. 8, 1969, 1A.

${ }^{16}$ Frank Wells, "100 Residents in SE Plan Blockbusting Fight," Atlanta Constitution, Nov. 24, 1971, 13A.

${ }^{17}$ Bill Jordan, "Scare Tactics Hit in DeKalb," Atlanta Constitution, April 1, 1970, 8C; "DeKalb to Probe Home 'Sold' Signs," Atlanta Constitution, May 17, 1972, 6A; Walter B. Russell, Jr., "DeKalb to Stabilize Transitional Neighborhoods," Atlanta Constitution, July 2, 1978, 2C. For further evidence of blockbusting in southwestern DeKalb in the early 1970s, see "Federal Judge Rules Against Blockbusting," Atlanta Daily World, April 23, 1970, 5; Owen Davis, "Stiff Blockbusting Penalties Urged," Atlanta Constitution, Oct. 29, 1971, 10A; "Bust the Busters," Atlanta Constitution, June 

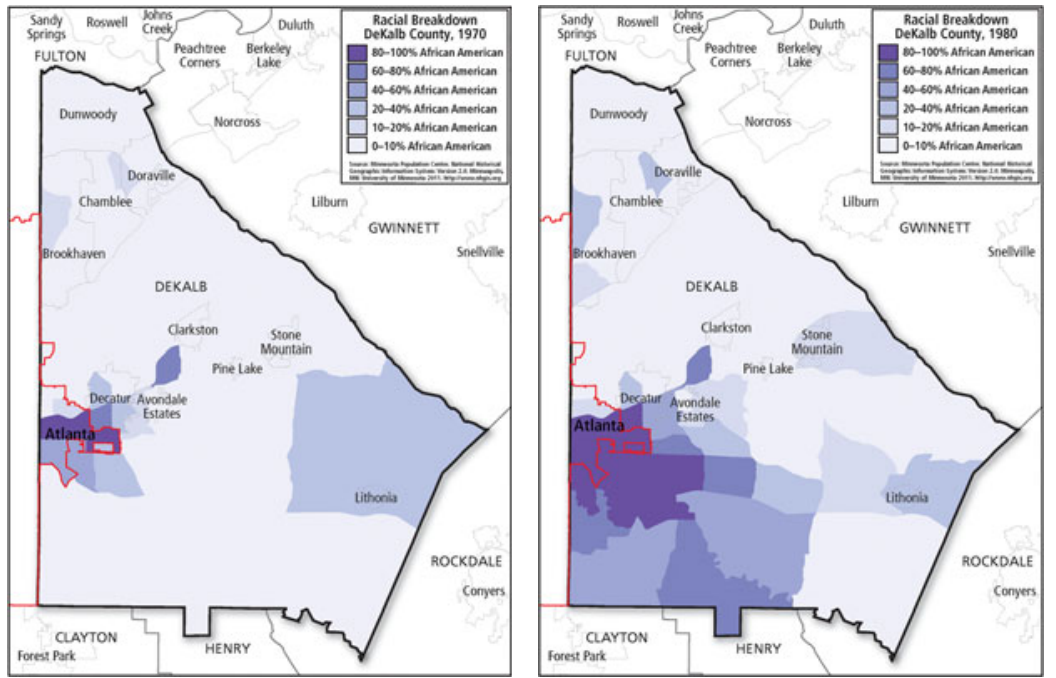

Figure 1 and Figure 2: Demographic change in DeKalb County, Georgia, 1970-1980. The red lines denote Atlanta's city limits. (Minnesota Population Center. National Historical Geographic Information System, Version 2.0. Minneapolis, MN: University of Minnesota, 2011, http://www.nhgis.org.)

Yet other forms of discrimination persisted in suburban DeKalb's housing market that likewise fostered new patterns of residential segregation. Racial steering was commonplace according to the head of Metro Fair Housing, Atlanta's leading nonprofit focused on housing discrimination. "When blacks seek houses, they are steered to integrated or black neighborhoods," she explained. Whites, by contrast, were led to white areas. ${ }^{18}$ At the same time, landlords and sellers often favored potential white buyers or renters over African American ones. Beginning in the late 1970s and early 1980s, Metro Fair Housing sponsored pairs of black and white volunteers to test the local rental market, a tactic that helped the agency win more than $\$ 100,000$ in damages on behalf of victims of housing

10, 1972, 4A; Tom Linthicum, "Tougher Realtor Rules Supported," Atlanta Constitution, Oct. 30, 1973, 11A; Chet Fuller, "Realty Push Miffs Owners," Atlanta Constitution, June 9, 1974, 2A; Mary B. Thomas, "Agency Fights 'White Flight," Atlanta Constitution, July 27, 1975, 6B.

${ }^{18}$ Colleen Teasley, "Racial Steering: How Prevalent in Metro Realty," Atlanta Constitution, April 22, 1979, 1C. 
discrimination. ${ }^{19}$ Although Metro Fair Housing served all parts of metro Atlanta, the organization's director noted that south DeKalb County was an area that kept the agency particularly "busy." 20

Take, for example, Morris Bankston, an African American man who attempted to rent a house in south DeKalb. After setting up an appointment by phone to view the home, Bankston revealed his race to the person at the other end of the line to see if his being African American posed a problem. The next day Bankston called to confirm the appointment and was told that the house had been rented. Responding to Bankston's complaint, testers from Metro Fair Housing visited the property and discovered that it was still available. The African American tester "reported being treated rudely," while the white tester was offered a lease. ${ }^{21}$ In addition, African American homebuyers sometimes learned that sellers who had rejected their offers had later sold to white buyers for similar prices. Of course, far more African American apartment and house hunters never discovered they had been discriminated against. Doubtless many of them ended up purchasing or renting homes in already integrated or predominantly African American areas where sellers and landlords were more open to African American buyers, such as those that blockbusting had previously impacted in southwestern DeKalb. Moreover, violence and intimidation were not unheard of in DeKalb County well into the 1980s, particularly when African Americans attempted to move into the county's north. In 1984, when an African American family moved to Doraville, an area deep in northern DeKalb County, the family had to endure repeated bouts of harassment. Young white men shouted racial slurs from car windows. The family's automobile was torched, and a cross was burned in the family's yard. ${ }^{22}$

Meanwhile, forces other than housing discrimination contributed to the racial reconfiguration of suburban DeKalb. A significant number of African Americans who bought homes in south DeKalb did so using FHA-backed loans, which became increasingly available to African American homebuyers after the 1968 Fair Housing Act's passage. FHA loans, of course, mainly subsidized home purchases for firsttime buyers, suggesting that a number of African American newcomers to suburban DeKalb County gained a new foothold in the middle class

19 “3 Housing Discrimination Cases in Atlanta Settled," Atlanta Daily World, Sept. 6, 1981, 1; Jim Auchmutey, "DeKalb Agency Fights Persistence of Racial Bias in Atlanta Housing," Atlanta Constitution, May 3, 1983, 10A.

${ }^{20}$ Pete Scott, "Metro Housing Bias Called Widespread: Organization Says It Plans to File Lawsuit," Atlanta Constitution, April 23, 1984, 1E.

${ }^{21}$ Auchmutey, "DeKalb Agency Fights Persistence of Racial Bias in Atlanta Housing."

${ }^{22}$ Sam Heys, "Racial Discrimination in the Suburbs," Atlanta Constitution, Oct. 19, 1984, $1 \mathrm{D}$. 
upon moving there. But that foothold proved tenuous for some. The sour economy of the 1970s led to a rash of foreclosures in south DeKalb, many of them on FHA-financed homes owned by African Americans. Rising rates of foreclosure provoked additional white flight from the area, as better-off white homeowners, wary of how foreclosures might impact property values, moved elsewhere. ${ }^{23}$

School officials and the court that oversaw DeKalb's school desegregation case also influenced the development of DeKalb's racial landscape. Like school systems across the South, the DCSD resisted the US Supreme Court's 1954 decision in Brown v. Board of Education for years. In the late 1960s, the DCSD was still operating four elementary schools and one high school that served solely African American children at a time when African American children constituted only 5.6 percent of the district's students. In 1968, the US Supreme Court issued its landmark ruling in Green v. County School Board of New Kent County (Virginia), which famously declared that it was time to end the foot-dragging and evasions that had followed Brown. In Green, the Supreme Court ordered school districts in the South to finally abolish the vestiges of de jure school segregation "root and branch." Within two months of the decision, a collection of African American parents in suburban DeKalb County filed suit in federal district court with the support of the DeKalb County NAACP to compel the DCSD to desegregate. Willie Eugene Pitts, an African American child whose mother, Anna Mae Pitts, brought suit on his behalf, was named lead plaintiff in the case. The DCSD's superintendent-first Jim Cherry and in later years Robert Freeman-was named defendant. ${ }^{24}$

${ }^{23}$ John Reetz, "Blight in DeKalb: Vacant Homes Tarnish County's Image," Atlanta Constitution, Nov. 20, 1977, 13B; Susan Wells, "South DeKalb Area Has Most Home Foreclosures in Nation," Atlanta Constitution, April 1, 1979, 9B.

${ }^{24}$ Green v. County School Board of New Kent County, 391 U.S. 430 (1968) at 438; Freeman v. Pitts, 503 U.S. 467, 475 (1992); "Other Information," undated, no folder, box 4, Pitts v. Freeman School Desegregation Case Files (MS 1036), Stuart A. Rose Manuscript, Archives, and Rare Book Library, Emory University, Atlanta (hereafter Pitts v. Freeman Papers MARBL). The Pitts v. Freeman papers held at Emory are an unprocessed collection of materials accumulated by lawyers who represented the plaintiffs in the case in their attempt to force the DeKalb County School District to meaningfully desegregate. Folder and other identifying information are not always available for materials cited from this collection. The case was referred to as Freeman v. Pitts at the U.S. Supreme Court level since the DCSD (i.e., Freeman, the name of the DCSD's superintendent at the time) filed the Supreme Court appeal. The case was called Pitts $v$. Freeman at lower levels of the federal judiciary for almost all of its history. When the case was finally dismissed in federal district court in 1996, the named plaintiff had changed from Pitts to Mills, as indicated in note 71 of this article. 
In light of the Green decision, in 1969 Federal District Court Judge Newell Edenfield approved a desegregation plan largely designed by DCSD officials and representatives of the US Department of Health, Education, and Welfare (HEW). Above all, the plan focused on closing the district's remaining all-African American schools and integrating their students into existing DCSD schools. It also entailed drawing new catchment zones for schools in the DCSD that would place all students, African American and white, in schools in or near their own neighborhoods. Edenfield and HEW officials apparently believed that the district could satisfactorily integrate within such a neighborhood-based system, most likely because the African American population in DeKalb County was still relatively small in 1969. Edenfield included a number of other mandates in his 1969 order, including desegregating the district's faculty and staff while ensuring that "the pattern of teacher assignment to any particular school not be identifiable as tailored for a heavy concentration of either Negro or white pupils." ${ }^{25}$ Additionally, he ordered DCSD officials to pursue the construction of new school buildings and the consolidation of students into existing facilities "with the objective of eradicating segregation and perpetuating desegregation." 26

The DCSD quickly closed its de jure all-African American schools after Edenfield issued his decree. Yet a new collection of overwhelmingly African American schools soon emerged in suburban DeKalb, particularly in the county's southwest. In 1969-the year the DCSD closed its de jure all-African American schools and implemented its new neighborhood-based catchment system-only one school in the DCSD was majority African American. By 1975, there were fourteen majority black schools in the district, all of them in southwestern portions of the county. Five of these schools were at least 96 percent African American, another was 91 percent African American, two more were 83 and 89 percent African American, respectively, and the rest were between 66 and 79 percent African American. The proportion of African American students in the DCSD as a whole was just 18 percent at the time. In short, merely six years after Judge Edenfield's original desegregation order, the DCSD had significantly

${ }^{25}$ Freeman v. Pitts, 503 U.S., joint app., vol. 1, 67. For Edenfield's 1969 decision in its entirety, see Freeman v. Pitts, 503 U.S., joint app., vol. 1, 61-70. Unless otherwise indicated, the federal district court decisions related to Freeman v. Pitts cited in this article are not available on Westlaw and are unpublished other than as part of the US Supreme Court's joint appendix for the case, which is what is cited here.

${ }^{26}$ Freeman v. Pitts, 503 U.S., joint app., vol. 1, 66. 
more schools that were effectively African American-only than the district had ever had under Jim Crow. ${ }^{27}$

School officials contributed to this trend, although dynamics in the housing market-including the discrimination previously described-were also formative. According to a $1976 \mathrm{HEW}$ investigation, DCSD officials gerrymandered catchment zones in ways that increased the number of predominantly African American high schools in southwestern DeKalb. Specifically, HEW officials found that zoning changes the DCSD implemented in 1974 increased the African American population of an already predominantly black high school (Gordon) and made another school (Walker) majority African American for the first time by lifting the proportion of black students in the school from 35 percent to 60 percent in just one year, a share that continued to grow quickly thereafter. DCSD leaders took similar steps in 1975 when they implemented feeder patterns that helped create a new majority African American high school in the district (Columbia), even though doing so forced some students to travel more than five miles to school. As HEW officials pointed out, adopting an alternative feeder pattern would have led to a more racially integrated school and a maximum commuting distance for students of only two and a half miles. ${ }^{28}$

DCSD officials also failed to fully desegregate the district's teaching force. In 1975, for example, multiple predominantly African American elementary schools in southwestern DeKalb had faculties that were between 40 and 48 percent African American at a time when the proportion of African American teachers in the district as a whole was merely 15 percent. Finally, as the number of predominantly African American schools in suburban DeKalb County rose, DCSD officials did little to counteract the trend. School leaders implemented a majority-to-minority (M-to-M) transfer program after the US Supreme Court declared M-to-M an "indispensable remedy" in Swann v. Charlotte-Mecklenburg Board of Education (1971). As originally designed, the DCSD's M-to-M initiative enabled children who were in the racial majority in their neighborhood school to transfer to the

${ }^{27}$ Freeman v. Pitts, 503 U.S., joint app., vol. 1, 253; Freeman v. Pitts, 503 U.S., joint app., vol. 2, 505-08; William H. Thomas to Newell Edenfield, June 3, 1976, [no folder], box 8, case file for 68-cv-11946, Pitts v. Freeman, National Archives at Atlanta (hereafter Pitts v. Freeman Papers NARA). The case file for Pitts v. Freeman held at the National Archives at Atlanta is an unprocessed collection that includes materials accumulated by the federal district court throughout the duration of the case. Folder and other identifying information are not always available for materials cited from this collection.

${ }^{28}$ William Thomas to Newell Edenfield, June 3, 1976; Freeman v. Pitts, 503 U.S., joint app., vol. 1, 76-79, 86-91; Freeman v. Pitts, 503 U.S., joint app., vol. 2, 505. 
next nearest school where they would be in the racial minority as long as that school was under capacity and its proportion of minority students was 40 percent or less. Yet DCSD officials provided no transportation for students enrolled in $\mathrm{M}$-to-M and made few efforts to advertise the program. By 1976, only ninety-six students in the DCSD took part in M-to-M. ${ }^{29}$

In the meantime, the development of an enclave of predominantly African American schools in southwestern DeKalb County began to influence racial settlement patterns in suburban DeKalb more generally. Suburban DeKalb's population-both black and white-grew significantly in the first half of the 1970s. Roughly thirty-five thousand whites moved to suburban DeKalb County between 1970 and 1975 compared to twenty thousand African Americans. The existence of an expanding set of predominantly African American schools-often staffed disproportionately by African American teachers-discouraged whites who were wary of integrated schooling or of having African American instructors teach their children from moving to southwestern DeKalb. Virtually no whites settled in that area in the first half of the 1970s, nor would they in later years. Moreover, the development of a clearly identifiable collection of African American schools in the DCSD made it all the easier for realtors to engage in racial steering or to profit from fomenting panic about racial change in southwestern DeKalb while promoting white flight through blockbusting. In sum, DCSD officials' ongoing resistance to school desegregation in the first half of the 1970s was yet another factor that contributed to new patterns of racial segregation, not only in suburban DeKalb County's schools but in its neighborhoods as well. ${ }^{30}$

The federal court that oversaw the DCSD's desegregation case declined to remedy this development, however, although it did fault DCSD officials for wrongdoing. In 1976, in response to a complaint brought by the case's plaintiffs, Judge Edenfield rebuked DCSD leaders for violating his 1969 decree in multiple ways. He took DCSD officials to task for failing to fully desegregate the DCSD's teaching force and once again ordered them to do so, specifically by making "the ratio of faculty in individual schools ... substantially similar to the system-wide ratio" of African American to white teachers. ${ }^{31} \mathrm{He}$ chastised DCSD leaders for not properly advertising the school district's M-to-M program and for failing to provide

${ }^{29}$ Freeman v. Pitts, 503 U.S., joint app., vol. 1, 73-76; Swann v. Charlotte-Mecklenburg Board of Education, 402 U.S. 1 (1971) at 26.

${ }^{30}$ Freeman v. Pitts, 503 U.S., joint app., vol. 1, 260.

${ }^{31}$ Freeman v. Pitts, 503 U.S., vol 1., 94. See also Freeman v. Pitts, 503 U.S., joint app., vol. 1, 84-86. 
transportation as part of M-to-M. He also demanded that DCSD officials make a handful of changes to the rules governing $\mathrm{M}$-to-M to expand the program's capacity and to make it easier for students to enroll. Finally, Edenfield agreed with HEW's assessment that DCSD officials had gerrymandered high school catchment zones in southwestern DeKalb in ways that had actively increased segregation rather than "perpetuating desegregation," as his 1969 decree had required. ${ }^{32}$ To prevent similar infractions in the future, Edenfield appointed a new "biracial committee" to review the school district's rezoning and construction plans moving forward. ${ }^{33}$

Edenfield's decision was a strong repudiation of DCSD officials' past actions, but the remedies that he mandated shied away from forcing DCSD leaders to address the effects of their earlier transgressions. Enrollment in M-to-M grew in the wake of Edenfield's ruling to about 1,100 of the DCSD's roughly 70,000 students by the early 1980s. The expansion of $\mathrm{M}$-to-M allowed an increasing number of African American students in the DCSD to transfer to majority white schools elsewhere in the district and, thus, to experience integrated schoolingan important trend. Yet the fact that African American students could transfer to majority white schools only if those schools had the capacity to house them placed sharp limits on how many African American students could participate in the program. High levels of segregation continued to plague the predominantly African American schools in southwest DeKalb. Meanwhile, the biracial committee that Edenfield created was designed to prevent future violations of the DCSD's desegregation decree when it came to rezoning and construction, not to remedy earlier violations. In its report on gerrymandering, HEW officials had urged Edenfield to implement measures that could help undo the damage of the DCSD's negligence in southwestern DeKalb while potentially fostering greater levels of desegregation in the school district in the future, including beyond what M-to-M alone could accomplish. For instance, HEW investigators proposed pairing majority African American schools with majority white schools in the DCSD and integrating their students. In a terse, unexplained statement, however, Edenfield rejected HEW's suggestions. Instead, he left the patterns of school segregation that had taken root in southwestern DeKalb largely undisturbed. Just as important, he did little to prevent the rise of additional majority African American schools in the

${ }^{32}$ Freeman v. Pitts, 503 U.S., joint app., vol. 1, 66. For Edenfield's discussion of gerrymandering, see, Freeman v. Pitts, 503 U.S., joint app., vol. 1, 76-79, 86-92. For his discussion of the M-to-M program, see Freeman v. Pitts, 503 U.S., joint app., vol. 1, 73-75, 79-84, 93-94.

${ }^{33}$ Freeman v. Pitts, 503 U.S., joint app., vol. 1, 94. 
DCSD moving forward. Rather, he kept the existing neighborhoodbased school plan intact even though it was clearly allowing racial segregation to reemerge in the DCSD. ${ }^{34}$

Edenfield's 1976 decision provided the framework for the DCSD's desegregation efforts for the next decade. By the mid1980 s, school officials had opened a handful of magnet programs, in part to further integration, but they served less than less than 1 percent of DCSD students. M-to-M remained the school district's primary tool for fostering desegregation. Although enrollment in M-to-M continued to grow, by 1987 only 6 percent of the DCSD's total student population and 11 percent of its African American population participated in the program. Absent a more aggressive intervention by the federal judiciary or a major voluntary push by DCSD officials beyond what Judge Edenfield had required, the number of predominantly African American schools in the DCSD continued to rise. By the mid-1980s, thirty-five out of ninety-seven schools in the DCSD were majority African American. All of them sat in the southern half of the county. Twenty-two of these schools were more than 90 percent African American. Since the DCSD continued to rely on neighborhoodbased feeder patterns, these numbers in part reflected the ongoing development of predominantly African American neighborhoods across southern sections of suburban DeKalb. ${ }^{35}$

To be sure, prominent figures within the DCSD hoped for a more aggressive attack on segregation in local schools, such as Phil McGregor, the sole African American member of suburban DeKalb's school board in the mid-1980s. But McGregor and his allies could not muster the power to reconfigure DCSD policy, which remained largely indifferent to school segregation. Indeed, once a majority of DeKalb's school board saw an opportunity to terminate the DCSD's desegregation order, they jumped on it, eventually spending hundreds of thousands of taxpayer dollars on a court battle that, in time, made its way to Washington, DC. Yet as the case progressed from hearings in district court to forming the basis of a major US Supreme Court decision, justices at different levels of the federal judiciary, including the Supreme Court itself, would fail to grapple adequately

\footnotetext{
${ }^{34}$ William Thomas to Newell Edenfield, June 3, 1976; Freeman v. Pitts, 503 U.S., joint app., vol. 1, 92, 253; Freeman v. Pitts, 503 U.S., joint app., vol. 2, 451.

${ }^{35}$ The DCSD served relatively few Latino, Asian, and other non-African American students of color at the time. Although a definitive number is difficult to glean from available data, all or nearly all sixty-two of the ninety-seven schools in the DCSD that were not majority African American were either majority white or close to majority white. Sixteen of those sixty-two schools were 10 percent African American or less. Freeman v. Pitts, 503 U.S., joint app., vol. 2, 475, 505-08; Freeman v. Pitts, 503 U.S., joint app., vol. 1, 218, 253.
} 
with a critical moment in the case's history. Ultimately, however, this error would constitute just one of the ways that problematic visions of history shaped the Supreme Court's ruling in Freeman. ${ }^{36}$

\section{Eliding the Past}

DCSD officials petitioned the federal district court to terminate its desegregation order in January 1986, immediately in the wake of yet another fight between plaintiffs and DCSD leaders. That conflict centered on the DCSD's plans to expand Redan High School, which was nearly all white, instead of potentially sending some of its students to nearby under-capacity schools that were predominantly African American. The Redan case lasted two years and entailed a district court decision, an appeal to the 11 th Circuit Court of Appeals, and a return to district court. The particulars of the controversy surrounding the expansion of Redan are less historically significant than what the case seemed to reveal about the judge, William O'Kelley, who replaced Edenfield in presiding over the DCSD's desegregation case after Edenfield's death in 1981. Judge O'Kelley was first appointed to the federal bench in 1970 by President Richard Nixon, an outspoken opponent of court-ordered desegregation. Not only did Judge O'Kelley rule in the school district's favor when it came to the Redan case, but his decision also stated that the DCSD was "unitary" - a technical term in court desegregation cases indicating that a school district had fully satisfied its legal obligation to desegregate and thus had gained the right to have its desegregation decree dissolved. Justices on the 11 th Circuit overturned O'Kelley's initial ruling, however, and ordered him to reconsider the Redan case. Among other criticisms, the appeals court contended that O'Kelley had failed to hold proper hearings to ascertain whether the DCSD had, in fact, achieved unitary status. Just months after O'Kelley issued a revised ruling focused on the Redan controversy (again in the school district's favor), DCSD officials asked O'Kelley to hold precisely those hearings and to terminate the court's desegregation decree once and for all. ${ }^{37}$

36"DeKalb Official Wants Court to Oversee Desegregation," Atlanta Daily World, July 19, 1987, 1. DCSD officials spent over \$400,000 on the case in 1990 and 1991 alone. "Summary of DeKalb Schools' Legal Expenses Requested by F. Pauley," Open Records folder, box 8, Pitts v. Freeman Papers MARBL.

${ }^{37}$ Freeman v. Pitts, 503 U.S., joint app., vol. 2, 505; Freeman v. Pitts, 503 U.S., joint app., vol. 1, 151-99. On the Redan High School controversy, see also Pitts v. Cherry Correspondence folder, box 2, Pitts v. Freeman Papers MARBL. Additional materials are interspersed in box 3 of the same collection and in the black binder in box 5 . For 
Yet after three weeks of testimony, O'Kelley found it difficult to grant that the DCSD had fully satisfied its desegregation order. Lawyers for the African American plaintiffs in the case presented powerful evidence that the DCSD spent less per capita on students in predominantly African American schools. They contended that faculties at majority African American schools in the district were generally less experienced and had lower levels of educational attainment than those at predominantly white schools. Additionally, the plaintiffs' counsel argued that many predominantly African American schools still had a disproportionate number of African American teachers and administrators, although the racial maldistribution of faculty and staff was less severe than in earlier years. Judge O'Kelley agreed with each of these points. ${ }^{38}$ At the same time, however, O'Kelley sided with DCSD officials and against the plaintiffs on another important matter. Specifically, O'Kelley held that the high rates of segregation among students in the district were not the DCSD's fault but rather had resulted simply from "where black and white families chose" to live. ${ }^{39}$ From this position, O'Kelley built on longestablished precedents in federal school desegregation law stipulating that school districts were not responsible for remedying so-called de facto school segregation-or segregation in schooling that a court deemed had been caused by forces separate from the actions of school or other government officials. ${ }^{40}$ Accordingly, O'Kelley ruled that DCSD leaders had to equalize resources and remedy the maldistribution of African American faculty and staff across the DeKalb system before he would terminate the court's desegregation order in its entirety. ${ }^{41}$ But he also declared that DCSD officials "had fulfilled their constitutional obligation" when it came to desegregating the district's student body. ${ }^{42}$ Thus, O'Kelley terminated that particular facet of the court's decree, thereby ending court oversight of how the DCSD designed school catchment areas or otherwise assigned students to schools. ${ }^{43}$

basic biographical information on Justice O'Kelley, see https://www.fjc.gov/history/ judges/okelley-william-clark.

${ }^{38}$ Freeman v. Pitts, 503 U.S., joint app., vol. 1, 224-236, 237-249.

${ }^{39}$ Freeman v. Pitts, 503 U.S., joint app., vol. 1, 230.

${ }^{40}$ Freeman v. Pitts, 503 U.S., joint app., vol. 1, 206-224. Historians have problematized and in many cases wholly debunked the notion of de facto segregation by showing the manifold ways that government entities and policies caused racial segregation in metropolitan America. See especially Matthew D. Lassiter, "De Jure/De Facto Segregation: The Long Shadow of a National Myth," in The Myth of Southern Exceptionalism, ed. Matthew D. Lassiter and Joseph Crespino (New York: Oxford University Press, 2010).

${ }^{41}$ Freeman v. Pitts, 503 U.S., joint app., vol. 1, 248-49.

${ }^{42}$ Freeman v. Pitts, 503 U.S., joint app., vol. 1, 224.

${ }^{43}$ Freeman v. Pitts, 503 U.S., joint app., vol. 1, 248-49. 
Leaving aside for now the merits of O'Kelley's stance on the roots of school segregation in suburban DeKalb, his ruling was novel in two respects. First, in weighing whether the DCSD had fulfilled its duty to desegregate, O'Kelley used six criteria that the Supreme Court had laid out in its 1968 Green decision-the so-called Green factors. According to Green, school officials needed to eradicate district-fostered segregation in (1) students' school assignments, (2) the distribution of faculty, (3) the distribution of staff, (4) access to transportation, (5) provision of extracurricular activities, and (6) school facilities. O'Kelley added a seventh criterion: quality of education. This addition was in part where the novelty of his ruling lay. More important, however, was O'Kelley's willingness to release the DCSD from its obligation to foster desegregation in some of the Green categories but not others. O'Kelley's ruling implied that a school district did not have to satisfy all of the Green categories at once. Instead, a school district could hypothetically fulfill and then be released from court oversight in just one or a handful of the Green categories at a time, much as O'Kelley had done when he ended the DCSD's obligation to desegregate its student body, even as he maintained court oversight in other realms. Meeting the Green factors incrementally, as O'Kelley's ruling suggested was acceptable, would potentially make it significantly easier for a school district to satisfy a court desegregation order than if it had to meet all of the Green criteria simultaneously for a sustained period. ${ }^{44}$

It was largely due to this theoretical issue that the case worked its way up to the US Supreme Court. On appeal, justices on the 11th Circuit overturned O'Kelley-both his ruling that a school district could satisfy Green incrementally and his position that the DCSD was no longer responsible for remedying student segregation in the school district. The justices on the Supreme Court, by contrast, largely took O'Kelley's side on the main theoretical question but divided sharply on other issues, especially whether O'Kelley was correct to release the DCSD from its obligation to desegregate its student population. Members of President George H. W. Bush's administration deemed the stakes of the case high enough that Solicitor General Kenneth Starr filed an amicus curiae brief in support of the DCSD. That brief was also signed by future Chief Justice of the Supreme Court John Roberts, who was then principal deputy solicitor general. ${ }^{45}$

\footnotetext{
${ }^{44}$ Freeman v. Pitts, 503 U.S., joint app., vol. 1, 202-50; Freeman v. Pitts, 503 U.S. at 467; Green v. County School Board of New Kent County, 391 U.S., at 435.

45 "Brief for the United States as Amicus Curiae Supporting Petitioners," no folder, box 10, Pitts v. Freeman Papers MARBL; Freeman v. Pitts, 503 U.S. at 470. When the case was heard, all but one of the justices on the Supreme Court had
} 
Associate Justice Anthony Kennedy wrote the court's decision, which Justices William Rehnquist, Byron White, Antonin Scalia, and David Souter also signed. ${ }^{46}$ On the issue of whether a federal court had the discretion to incrementally release a school district from a desegregation decree, Kennedy argued that a court not only had that power but should exercise it when possible, since a specific remedy to a constitutional violation-in this case de jure segregated schooling- "is justifiable only insofar as it advances the ultimate objective of alleviating" that violation. ${ }^{47}$ Nonetheless, drawing on earlier legal precedents, Kennedy emphasized that a court should release a school district from a facet of its desegregation decree only under certain conditions, including "whether there has been full and satisfactory compliance with the decree in those aspects of the system where supervision is to be withdrawn." 48

Kennedy then went on to evaluate whether the DCSD had met this criterion- "full and satisfactory compliance"-when it came to desegregating its student body. In so doing, Kennedy for the most part endorsed Federal District Court Judge O'Kelley's position that the DCSD had successfully met the requirements of this facet of its desegregation decree. O'Kelley's decision, however, had failed to address a pivotal moment in the case's history. Recall that O'Kelley released the DCSD from the part of its desegregation decree focused on desegregating students because he had found that the segregation that pervaded DCSD schools was a result of "where black and white families chose to live." ${ }^{49}$ O'Kelley declared that he saw no "persuasive evidence" that the actions of DCSD officials had helped cause segregation in the district, and thus O'Kelley concluded that DCSD officials were not required by law to fix it. ${ }^{50}$ Yet absent from O'Kelley's decision was any significant discussion of Judge Edenfield's 1976 ruling or of HEW investigators' findings that DCSD leaders had violated Edenfield's original desegregation decree on multiple fronts, including by gerrymandering high school catchment zones in ways that fostered segregation and by failing to fully desegregate the district's teaching force so as to prevent the "racial identifiability" of schools. ${ }^{51}$

been appointed by Republican presidents, specifically by Nixon, Ford, Reagan, and George H. W. Bush. John F. Kennedy had appointed the remaining justice.

${ }^{46}$ Freeman v. Pitts, 503 U.S. at 470.

${ }^{47}$ Freeman v. Pitts, 503 U.S. at 489.

${ }^{48}$ Freeman v. Pitts, 503 U.S. at 491.

${ }^{49}$ Freeman v. Pitts, 503 U.S., joint app., vol. 1, 230.

${ }^{50}$ Freeman v. Pitts, 503 U.S., joint app., vol. 1, 223.

${ }^{51} \mathrm{O}$ 'Kelley offered a summary of past litigation in the case in a footnote, writing that in 1976 plaintiffs had "challenged the M-to-M program, staff assignments, and changes in attendance zones." He then noted that this challenge by the plaintiffs 
At one point in his decision, O'Kelley did consider whether changes in school catchment zones might have encouraged student segregation in the DCSD. His decision drew on the testimony of an expert witness for the DCSD regarding the issue. That witness claimed that he saw little evidence that alterations to school catchment areas since 1969 had increased school segregation in the district to a significant degree, which the witness defined as expanding a given school's African American population "by more than five percentage points." The witness's testimony, however, did not directly discuss any of the high schools impacted by the gerrymandering that Edenfield had focused on in his 1976 decision and that HEW investigators had identified, nor did the main exhibit submitted to support the witness's findings. ${ }^{52}$ Even a cursory glance at the racial makeup of those high schools before and after the gerrymandering occurred suggests that the proportion of African American students in two of them grew by 25 percent and nearly 14 percent, respectively, significantly more than the expert witness's 5 percent baseline. O'Kelley did not note these discrepancies in his decision, nor did he explore why the findings of the DCSD's expert witness might have differed from those of Edenfield and the HEW investigators. O'Kelley also did not grapple with how the DCSD's failure to desegregate its faculty had impacted racial settlement patterns in suburban DeKalb. ${ }^{53}$

had resulted in adjustments to M-to-M, an order to reassign staff to "approximate the system-wide percentages," and the formation of the biracial committee. He did not, however, explain that the biracial committee was a remedy that sprang from past gerrymandering of school zones. Later in the decision, O'Kelley did discuss Edenfield's finding that the DCSD had failed to desegregate its teaching force, but as noted in this article, he did not explore how this violation led to the "racial identifiability" of schools in the DCSD and, in turn, may have helped to encourage racial segregation in DeKalb's schools and neighborhoods. Freeman v. Pitts, 503 U.S., joint app., vol. 1, 203n1, 226-27.

${ }^{52}$ Freeman v. Pitts, 503 U.S., joint app., vol. 1, 424. For the pertinent testimony, see "Testimony of David J. Armor," vol. 31 of 52 folder, box 5, case file for 68-cv11946, Pitts v. Freeman Papers NARA. As noted in the following paragraph, Armor's testimony was submitted to the US Supreme Court for consideration, including as part of the joint appendix for the case. Freeman v. Pitts, 503 U.S., joint app., vol. 2, $552-657$.

${ }^{53}$ William Thomas to Newell Edenfield, June 3, 1976; Freeman v. Pitts, 503 U.S., joint app., vol. 2, 505. During trial in O'Kelley's court, depositions by expert witnesses for both the African American plaintiffs and the DCSD said little about how the DCSD's failure to fully desegregate its faculty impacted racial settlement patterns and school segregation in suburban DeKalb. Overall, at the district court level, the plaintiffs' lawyers seemed to take for granted the salience of Edenfield's 1976 findings in eliciting testimony and in building their case more generally and thus, in retrospect, perhaps unintentionally left room for Edenfield's 1976 ruling to figure only peripherally in O'Kelley's decision. See especially "Testimony of David J. Armor"; 
On multiple occasions in oral arguments before the US Supreme Court, the lead counsel for the African American plaintiffs in the case underscored O'Kelley's failure to wrestle with Edenfield's 1976 decision. "The district court found in '76 that the student assignment segregation in this district was not purely ... a result of demographics," the lawyer argued. "Now, the district court in '86 appears to ignore ... its own '76 holding." 54 Moreover, a copy of Edenfield's 1976 decision (which cited and drew repeatedly on HEW's investigation) was included in the materials submitted to the US Supreme Court for consideration, as were the testimony of the expert witness mentioned above, the pertinent exhibit related to that testimony, and figures for the racial makeup of every DCSD school from 1969 through the mid1980s, including for the schools and years noted in Edenfield's 1976 decision. Even so, Kennedy-like O'Kelley before him-failed to engage with Edenfield's and HEW's findings, despite the pleas of the plaintiffs' attorney. ${ }^{55}$

Indeed, Kennedy utilized a remarkably low bar for measuring "full and satisfactory" adherence to a desegregation decree-again, the criterion that Kennedy stated was essential for evaluating whether a school district could be released from a particular facet of a desegregation order. In fact, Kennedy contended that the DCSD had actually met its obligation to desegregate its students long before-in 1969, when school officials had first implemented the court's initial desegregation order mainly by closing down its historically de jure African American schools. Specifically, Kennedy wrote that the district court's 1969 desegregation decree "accomplished its objective in the first year of operation, before dramatic demographic changes altered residential patterns" in south DeKalb County. ${ }^{56}$ Paraphrasing O'Kelley, Kennedy further emphasized that those demographic shifts were "not attributable to the former de jure regime or any later actions by school officials [emphasis added]." 57 Since Kennedy found that the DCSD had done nothing to encourage the segregation that had developed in the

\footnotetext{
"Testimony of William A. V. Clark," vol. 27 of 53 folder, box 5, case file for 68-cv11946, Pitts v. Freeman Papers NARA; "Testimony of Robert A. Dentler," vol. 35 of 52 folder, box 5, case file for 68-cv-11946, Pitts v. Freeman Papers NARA; and "Testimony of Christine Rossell," vol. 37 of 52 folder, box 6, case file for 68-cv11946, Pitts v. Freeman Papers NARA.

${ }^{54}$ For a transcript of oral arguments in the case, see https://www.oyez.org/cases/ $1991 / 89-1290$.

${ }^{55}$ Freeman v. Pitts, 503 U.S., joint app., vol. 1, 71-95, 424; Freeman v. Pitts, 503 U.S., joint app., vol. 2, 505-08, 552-657.

${ }^{56}$ Freeman v. Pitts, 503 U.S. at 493-94.

${ }^{57}$ Freeman v. Pitts, 503 U.S. at 496; Freeman v. Pitts, 503 U.S., joint app., vol. 1, 223.
} 
district's schools after 1969, he concluded that O'Kelley had been right to treat school segregation in the DCSD as purely de facto and thus to exonerate DCSD officials from having to remedy it by terminating the facet of the district court's desegregation order focused on student assignment. $^{58}$

The low bar that Kennedy, along with the four other justices who signed his opinion, set in measuring full and satisfactory compliance arguably sent a clear message to federal judges across the country that a majority of Supreme Court justices would no longer expect particularly detailed scrutiny of the historical specifics of desegregation cases. On the contrary, elsewhere Kennedy-moving beyond the particulars of the DCSD case and of O'Kelley's decision-suggested that district courts could potentially view history-specifically the passage of time - as a factor that could actually mitigate a school system's obligation to desegregate. As Kennedy wrote, "As the de jure violation becomes more remote in time and these demographic changes intervene, it becomes less likely that a current racial imbalance in a school district is a vestige of the prior de jure system. The causal link between current conditions and the prior violation is even more attenuated if the school district has demonstrated its good faith" in attempting to follow its desegregation decree. ${ }^{59}$

Kennedy did not ground these assertions in testimony offered by expert witnesses in the DCSD case nor in social scientific findings. Instead, what Kennedy posited regarding the "causal link" between past discriminatory acts by school officials, neighborhood demographic change, and the racial makeup of particular schools was merely theory, specifically a theory of history that treated the passage of time as a force that could ameliorate historic wrongs and that downplayed the power of the past-even America's long history of racial discrimination-to structure the present. Rather than requiring federal judges to interrogate history and its ongoing impact, Kennedy's stance suggested that federal judges instead could ahistorically assume that time-combined with the "good faith" efforts of school officials-lessened the influence of a school district's past misdeeds.

\footnotetext{
${ }^{58}$ Kennedy said little to nothing in his opinion regarding DCSD initiatives like M-to-M or magnet schools other than in summarizing the facts of the case. Rather, his focus on the 1969 decree suggests that, at least when it came to the DCSD, Kennedy saw such programs as unnecessary — as merely voluntary - in terms of satisfying the school district's duty to desegregate its student population. Only closing the district's remaining de jure all-African American schools in 1969 had been necessary to achieve full and satisfactory compliance with that facet of the district court's desegregation decree.

${ }^{59}$ Freeman v. Pitts, 503 U.S. at 496.
} 
Kennedy's use of the concept of "good faith" built on a desegregation case, Board of Education of Oklahoma City v. Dowell (1991), which the Supreme Court had decided a year earlier. Kennedy incorporated other concepts from Dowell into his decision in Freeman as well, including the notion that district courts should weigh whether school districts had eradicated "vestiges of past discrimination ... to the extent practicable" when considering whether to terminate desegregation decrees. Again building on Dowell, Kennedy also emphasized that "federal judicial supervision of local school systems was intended as a "temporary measure" and contended, "Returning schools to the control of local authorities at the earliest practicable date is essential to restore their true accountability in our governmental system." 60

By using the court's decision in Freeman not only to address the particulars of the DCSD case but also to reaffirm and clarify the court's holdings in Dowell, Kennedy contributed to an emerging legal understanding of how district courts might bring the era of court-mandated school desegregation to an end. As scholars Sean F. Reardon and John T. Yun have observed, earlier Supreme Court decisions like Green had demanded that school systems desegregate in ways that "work, and work now." By contrast, Kennedy asserted in Freeman (building on Dowell) that school districts merely had to show that they had tried in earnest to desegregate to a vaguely defined "practicable" extent over a period of time. ${ }^{61}$ Moreover, Kennedy suggested, the passage of time itself could lessen a school districts' ongoing obligation to try to desegregate, since the impact of earlier de jure violations might be taken to fade as history progressed. Finally, by agreeing with Judge O'Kelley's position in the DCSD case, Kennedy made clear that school districts could satisfy their court desegregation orders piecemeal-in other words, by meeting each of the Green factors incrementally rather than simultaneously for a sustained period. On multiple fronts, then, Kennedy sought to hasten desegregation's end while returning full control of school systems across the country to local authorities.

Kennedy largely upheld the rest of O'Kelley's decision as well, including O'Kelley's order that the DCSD fix the maldistribution of African American and white faculty and staff and equalize resources across DCSD schools. Still, Kennedy argued that O'Kelley needed to reconsider certain parts of his opinion, especially his tendency to treat the Green factors as independent of one another in assessing

${ }^{60}$ Freeman v. Pitts, 503 U.S. at 489, 490; Board of Education of Oklahoma City v. Dowell, 498 U.S. 237 (1991) at 249-50.

${ }^{61}$ Sean F. Reardon and John T. Yun, "Integrating Neighborhoods, Segregating Schools: The Retreat from School Desegregation in the South," in School Resegregation, ed. Boger and Orfield, 68n3. 
whether to release the DCSD from individual aspects of its desegregation order. Kennedy contended that doing so was not necessarily appropriate. Thus, Kennedy added another criterion for courts to use when weighing whether to release a school district from an individual facet of a desegregation decree: whether supervision of that part of the decree was "necessary or practicable" for satisfying other facets of the decree. ${ }^{62}$ Specifically, Kennedy stated that O'Kelley needed to review whether ending court oversight of student assignment patterns would hinder the DCSD's ability to address the racial maldistribution of teachers in the district. According to Kennedy, however, it seems that this task was largely a matter of principle when it came to the DCSD. Kennedy expressed skepticism that O'Kelley's court would have to maintain oversight of student assignments in the DCSD since "the record does not show that student reassignments would be a feasible or practicable way to remedy" the faculty and staff issue. Instead, Kennedy was inclined to agree with O'Kelley that a relatively small number of teacher and staff transfers could solve the problem. Even so, Kennedy continued, since O'Kelley did not have the Supreme Court's "analysis before it" when deciding the case, "further proceedings are appropriate." 63 Thus, Kennedy and the court remanded the case for additional review.

Officially speaking, Freeman v. Pitts was an 8-0 decision. (Clarence Thomas had yet to fill a seat that was open when the case was argued and thus did not take part in the court's deliberations.) But this unanimity primarily applied to only the most rudimentary judgment in the case, particularly that it be remanded to lower levels of the federal judiciary for further consideration. Despite agreeing on that front, three Supreme Court justices declined to sign Kennedy's opinion and instead filed a separate one that sharply rejected large portions of O'Kelley's decision and how Kennedy and the rest of the court had evaluated it, including their theory of history as discussed above. ${ }^{64}$

"It is almost 38 years since this Court decided Brown v. Board of Education," Justice Harry Blackmun wrote in an opinion that Justices Sandra Day O'Connor and John Paul Stevens joined in signing. "In those 38 years the students of DeKalb County, Ga., never have

${ }^{62}$ Freeman v. Pitts, 503 U.S. at 497.

${ }^{63}$ Freeman v. Pitts, 503 U.S. at 498.

${ }^{64}$ These three justices did not file a simple concurrence but an opinion "concurring in the judgment" of the court only. More specifically, they agreed with the rest of the court's judgment that the case needed to be remanded, but they disagreed with Kennedy and the rest of the court regarding the criteria that federal judges should utilize in evaluating compliance in school desegregation cases, including the DCSD case once it was revisited on remand. See Freeman v. Pitts, 503 U.S. at 509-518. 
attended a desegregated school system even for one day." 65 Blackmun particularly took issue with Kennedy and the majority of the court's assessment of how Judge O'Kelley had gauged compliance in certain aspects of the DeKalb case, such as the area of student assignmentone of the so-called Green factors that O'Kelley had released DCSD officials from having to pursue further. Among other complaints, Blackmun argued that O'Kelley had failed to aggressively examine whether school board policies had contributed either to residential segregation (and, in turn, to school segregation) or to the segregation of students more directly. Blackmun especially took O'Kelley to task for dismissing the need to scrutinize such dynamics in the past. As Blackmun noted, O'Kelley had proclaimed in his decision that he would "not dwell on what might have been," but instead would focus on "what else should be done now." By contrast, Blackmun asserted, "But this court's decisions require the District Court to 'dwell on what might have been' [emphasis in the original]. In particular, they require the court to examine the past to determine whether the current racial imbalance in the schools is attributable in part to the former de jure segregated regime or any later actions by school officials." 66 While Kennedy and a majority of the court embraced a theory of history that loosened federal judges' obligation to scrutinize the past and its ongoing impact, Blackmun contended that historical inquiry must remain central to determining a school district's ongoing obligation to desegregate.

Blackmun then homed in on the very slice of the past that Kennedy and O'Kelley largely ignored: the period from 1969-the inception of the DCSD's desegregation order-to 1976, when Edenfield and HEW officials had found the DCSD in violation of the court's decree in multiple ways. ${ }^{67}$ Quoting Green, Blackmun argued that school district officials bore the burden of proving that this era of noncompliance did not prevent the district from transitioning "to a system without a 'white' school and a 'Negro' school, but just schools." ${ }^{8}$ Given the persistence of highly segregated schools in DeKalb County when the Supreme Court heard the case in the early 1990s, and the fact that the DCSD was found out of compliance from 1969 to 1976, Blackmun rightly concluded, "The available evidence suggests that this would be a difficult burden" for DCSD officials "to meet." 69

${ }^{65}$ Freeman v. Pitts, 503 U.S. at 509.

${ }^{66}$ Freeman v. Pitts, 503 U.S. at 515.

${ }^{67}$ Freeman v. Pitts, 503 U.S. at 516-18.

${ }^{68}$ Freeman v. Pitts, 503 U.S. at 517-18; Green v. County School Board of New Kent County, 391 U.S. at 442.

${ }^{69}$ Freeman v. Pitts, 503 U.S. at 518. 
Blackmun's opinion pointed toward a history of the DeKalb County case that was far more accurate than Kennedy's. But it was Kennedy who had the votes to shape the case's future and the future of desegregation efforts in school districts across the nation. Taking cues from decisions like Freeman (as well as Dowell), school officials throughout the country began petitioning district courts to end their desegregation orders. Over the next two decades, federal judges would oblige in over two hundred cases. As the twentieth century came to a close, the era of school desegregation began to wane as well-in DeKalb County, Georgia, and across the United States. ${ }^{70}$

\section{Conclusion}

It did not take long for DCSD officials to convince Judge O'Kelley to terminate the DCSD's desegregation order-at least not after the case finally wended its way back down to O'Kelley's court. In 1994, at the request of DCSD leaders, O'Kelley initiated hearings to determine whether school officials had satisfied the facets of the court's desegregation decree that they had failed to meet when O'Kelley had last considered the case-specifically the assignment of faculty and staff, the distribution of educational resources, and quality of education. Following the Supreme Court's directive, O'Kelley also weighed the "good faith effort" of DCSD leaders to implement the court's desegregation order. Basing his decision almost exclusively on evidence presented by DCSD lawyers, O'Kelley determined that DCSD leaders had indeed met these parts of the decree, thanks in part to a handful of steps that they had taken since he had last heard the case, including implementing a lottery to redistribute faculty with twenty-plus years of experience to predominantly African American schools and expanding the district's magnet programs, which grew to serve over five thousand students in the district in the 1990s - a significant expansion in comparison to earlier years, though still a small proportion of the ninety thousand-plus students then in the district. Ongoing demographic shifts in the county doubtless helped the school district's case as well. The proportion of African American students in the district had continued to grow since O'Kelley had last considered the case. The number of Latino and Asian students had also increased. Roughly three-quarters of the students in the DCSD were African American, nearly 12 percent were Latino or Asian, and about 12 percent were white. (The proportion of whites in suburban DeKalb County in general was around 34 percent at the time, but many whites in the area were older empty nesters, while others sent their children to

\footnotetext{
${ }^{70}$ Reardon, et al., "Brown Fades," 876.
} 
private schools. $)^{71}$ In the 1995-96 academic year, O'Kelley noted, "only nine elementary schools and no secondary schools had a majority white population." 72 Demographics like these, O'Kelley contended, made it difficult to label schools as simply "white" or "black" and, in turn, made it hard to glean a discernable pattern of racial bias across district schools based on the evidence before him. After praising school officials for their "good faith effort" on all fronts, O'Kelley declared that the DCSD "has fully remedied the constitutional violation caused by its former maintenance of a dual system. All injunctive decrees are hereby dissolved, and the DeKalb County School System shall hereby resume full control over the operation of the schools which are within its jurisdiction." 73

O'Kelley's proclamation meant that the DCSD was no longer obligated to desegregate. Instead, it was merely bound by law not to discriminate. As was the case elsewhere in the United States, this distinction left race-based initiatives such as magnet programs and the district's M-to-M program vulnerable to attack. DCSD officials continued to run $\mathrm{M}$-to-M and its magnet schools for a time after O'Kelley's ruling. In the late 1990s, however, the school district stopped using race as a factor in admissions to the district's magnet programs after a collection of white parents and a conservative lawyer sued the district for discriminating against white children. The district ended M-to-M soon thereafter when a local conservative foundation threatened to sue the district on similar grounds. Responding to political pressure, district leaders tinkered with ways to continue M-to-M under different, non-race-based rules, including a program allowing students in schools in the DCSD that were over capacity (which lay mainly in predominantly African American areas of the county) to transfer to schools that were under capacity (which sat in comparatively white neighborhoods). Yet as had been the case for M-to-M, such small-scale initiatives held limited potential for counteracting

${ }^{71}$ Mills v. Freeman, 942 F.Supp. 1449 (N.D. Georgia, 1996); "Final Dismissal of DeKalb Desegregation Suit Asked," Atlanta Daily World, Oct. 25, 1994, 1; "History of School Desegregation in DeKalb County," Principles folder, box 3, Pitts v. Freeman Papers MARBL; Robert Anthony Watts, "Faced with Busing, DeKalb Weighs the Impact of Its Magnet Force," Atlanta Constitution, May 6, 1991, D1-2; "Magnet Schools," Defendant's Materials folder, box 1, Pitts v. Freeman Papers MARBL; "Magnet Schools," Plaintiff's Info folder, box 1, Pitts v. Freeman Papers MARBL; Bill Torpy, "Bitter Lessons: DeKalb Schools' 30-Year Struggle for Racial Balance Has Led to Resegregation, and the Question: What Was Gained?," Atlanta Constitution, Sept. 30, 1999, A1; US Census Bureau, 2000 Census of Population and Housing, Summary Population and Housing Characteristics, PHC-1-12, Georgia (Washington, DC: US Government Printing Office, 2002), 72.

\footnotetext{
${ }^{72}$ Mills v. Freeman, 942 F.Supp. 1449 (N.D. Georgia, 1996) at 1458.

${ }^{73}$ Mills v. Freeman, 942 F.Supp. 1449 (N.D. Georgia, 1996) at 1462 and 1464.
} 
racial isolation in the district. By 1999, approximately two-thirds of the African American students in the DCSD attended schools that were over 90 percent African American. ${ }^{74}$

The new patterns of racial segregation that took hold in suburban DeKalb County in the late twentieth century were rooted in multiple processes. The well-documented weaknesses of the 1968 Fair Housing Act - which relied primarily on victims of housing discrimination pursuing often time-consuming, expensive litigation - and the failure of Georgia state officials to police discrimination allowed blockbusting, racial steering, and in some cases intimidation to redefine the demographic makeup of south DeKalb County in the 1970s and 1980s. A foreclosure crisis in the 1970s further encouraged the reconfiguration of suburban DeKalb's racial landscape, as did a variety of educational dynamics.

Scholars such as Ansley Erickson and Andrew Highsmith have recently drawn attention to the role that schools have historically played in shaping racial settlement patterns in metropolitan America. ${ }^{75}$ Historians of African American suburbanization, however, have yet to act on this insight, particularly when examining the late twentieth century. The story of suburban DeKalb County's racial transformation during that period underscores the importance of doing so. Judge Edenfield's 1969 court desegregation decree closed the DCSD's historically de jure segregated all-African American schools, but the neighborhood school plan that he implemented did little to prevent the quick resurgence of predominantly African American schools in the DCSD. School district officials' consistent violation of Judge Edenfield's 1969 desegregation order in the early 1970s-especially failing to desegregate the district's teaching force and gerrymandering school catchment zones in ways that fostered segregation-helped fuel this trend, including compounding the racial identifiability of schools in southwestern DeKalb, thus exacerbating existing racial biases in suburban DeKalb's real estate market. While Edenfield chastised district officials on these fronts in his 1976 decision, he did not order measures that might have stemmed the growing racial isolation of African

74"DeKalb Schools Deseg Program Changes Concern Southside Parents," Atlanta Daily World, Dec. 9, 1999, 1; Torpy, "Bitter Lessons"; "Student Transfer Program Attacked," Atlanta Constitution, Feb. 2, 1999, B2; and "DeKalb Votes End to Racial Busing," Atlanta Constitution, Dec. 7, 1999, C1.

${ }^{75}$ Erickson, Making the Unequal Metropolis, Highsmith, Demolition Means Progress; and Highsmith and Erickson, "Segregation as Splitting and Joining." See also the other works listed in note 10 . 
American students in the DCSD, such as busing to desegregate schools in south DeKalb County. By roughly 1980, large portions of south DeKalb could be conceived of as "black neighborhoods" with "black schools," patterns that shaped the local real estate market and school demographics for years to come. Even at their height, school district initiatives like the M-to-M program and magnet schools were far too limited to counteract these trends.

Indeed, a major irony sits at the core of the story recounted here. The school district that was the focus of Freeman v. Pitts - again, one of the main US Supreme Court cases that helped bring the era of school desegregation to a close-had desegregated only modestly in the first place. The federal judiciary's retreat from school desegregation was felt far more acutely in places like Charlotte and Nashville, where the termination of court oversight meant the end of wide-ranging busing and a quick return to often-segregated, neighborhood-based schooling. ${ }^{76}$

To be sure, African American settlement in south DeKalb County was partly an expression of the housing preferences of some African American newcomers to the suburbs. Hardly all African American suburbanites sought to settle in integrated neighborhoods. Nonetheless, Judge O'Kelley's 1988 assertion that segregation in DeKalb County had resulted simply from "where black and white families chose" to live was deeply flawed, as was the Supreme Court's position that segregation in DeKalb County schools was not the result of "any ... actions by school officials" in the wake of the district court's original 1969 desegregation decree.

On the contrary, this assertion by the Supreme Court hinged on the erasure of a significant moment in the history of the DCSD case. As we have seen, however, the court's decision in Freeman downplayed the importance of the past in other ways as well. By the time Freeman was decided in the early 1990s, years of conservative political activismfueled in part by white resistance to school integration-had remade the US Supreme Court. Once a proponent of school desegregation, the court now sought to hasten desegregation's end, even by way of historical sleights of hand.

${ }^{76}$ See, for instance, Erickson, Making the Unequal Metropolis, 295-96; Roslyn Arlin Mickelson, "The Incomplete Desegregation of Charlotte-Mecklenburg Schools and Its Consequences," in School Resegregation, ed. Boger and Orfield, 87; Jennifer B. Ayscue, et al., "Segregation Again: North Carolina's Transition from Leading Desegregation Then to Accepting Segregation Now" (Los Angeles: UCLA Civil Rights Project, 2014), https://civilrightsproject.ucla.edu/research/k-12-education/ integration-and-diversity/segregation-again-north-carolina2019s-transition-fromleading-desegregation-then-to-accepting-segregation-now/Ayscue-WoodwardSegregation-Again_Executive.pdf. 